\title{
PREDICTION EQUATIONS FOR ESTIMATING 150 DAYS MILK YIELD FROM PART YIELDS IN TURKISH AWASSI SHEEP
}

\author{
Seyrani Koncagül ${ }^{1}$, Halit Deniz Şireli ${ }^{2}$, Nihat Tekel ${ }^{2}$, \\ Mehmet Emin Vural ${ }^{3}$, Ahmet Karataş ${ }^{3}$, Nalan Akça ${ }^{3}$ \\ ${ }^{1}$ Department of Animal Science, Faculty of Agriculture, University of Harran, Sanliurfa, 63200, Turkey \\ ${ }^{2}$ Department of Animal Science, Faculty of Agriculture, University of Dicle, Diyarbakir, 21100, Turkey \\ ${ }^{3}$ GAP International Agricultural Research and Training Center, Diyarbakir, 21120, Turkey \\ m_seyrani_n@yahoo.com
}

\begin{abstract}
This study was conducted to develop the prediction equations for 150 day milk yield on the cumulative part lactation milk yield records of Awassi sheep in the southeastern region of Turkey. In the study, a total of 145 sheep lambed during the 2007-2008 lambing year. Among the single monthly yields, the $3^{\text {rd }}$ month $\left(R^{2}=0.836\right)$ was the best for 150 days prediction followed by $2^{\text {nd }}$ and $4^{\text {th }}$ month $\left(R^{2}=0.756\right.$ and 0.659 , respectively). Among the cumulative monthly yields, the $T M Y 0_{4}\left(R^{2}=0.982\right)$ was the best for 150 days prediction followed by $T M Y 0_{3}, T M Y 0_{2}$ and $T M Y 0_{1}\left(R^{2}=0.926,0.797\right.$ and 0.659 , respectively). The phenotypic correlation was the highest between the LSV150 and $\mathrm{TMYO}_{4}(r=0.991)$ followed by $T M Y 0_{3}, T M Y 0_{2}$ and $T M Y 0_{1}(0.962,0.893$ and 0.775 , respectively). It was concluded that the total milk yield of the first three month after lambing could accuratly be used to predict the total lactation milk yield of Awassi sheep if there is lactation.
\end{abstract}

Key words: Turkish Awassi sheep; part lactation yields; prediction

\section{РАВЕНКИ ЗА ПРОЦЕНУВАЊЕ НА ПРИНОСОТ НА МЛЕКО ВО ПЕРИОД ОД 150 ДЕНА КАЈ ТУРСКИ ОВЦИ АWASSI}

\begin{abstract}
Студијата беше спроведена за да се развијат равенки за предвидување на вкупното лактациско млеко врз база на процена на млекото во текот на 150 дена од лактацијата кај контролирано стадо овци од расата Awassi во југоисточниот регион на Турција. Во рамките на студијата, вкупно 145 овци се ојагнија во текот на 2007-2008 година. Од поединечните месечни количини третиот месец $\left(R^{2}=0,836\right)$ беше најдобар од 150 дневниот период, а по него следат вториот и четвртиот месец $\left(R^{2}=0,756\right.$ и 0,659 , соодветно). Меѓу кумулативните месечни количини, $\mathrm{TMYO}_{4}\left(\mathrm{R}^{2}=0,982\right)$ е најдобар за 150 -дневното предвидување, а потоа следат $T M Y 0_{3}, T M Y 0_{2}$ и $T M Y 0_{1}\left(R^{2}=0,926,0,797\right.$ и 0,659 , соодветно). Фенотипската корелација е највисока меѓу LSV150 и $T M Y 0_{4}(r=0,991)$, потоа следат $T M Y 0_{3}, T M Y 0_{2}$ и $T M Y 0_{1}(0,962,0,893$ и 0,775, соодветно). Беше заклучено дека вкупната продукција на млеко од првите три месеци по јагнењето може прецизно да се искористи за предвидување на вкупното лактациско млеко кај овците Awassi, доколку има лактација.
\end{abstract}

Клучни зборови: турски овци Awassi; делумни лактациски приноси: предвидување

\section{INTRODUCTION}

Dairy sheep industry has been growing in Turkey, especially in the southeastern part of the country where there is a strong tradition for dairy sheep farming holding the Awassi sheep breed. Although there are some other milk type sheep breeds such as Chios, Norduz and newly identified Zom sheep (Koncagul et al., 2012; Koncagul et al., 2012), Awassi has a great importance in terms of sheep milk production in comparison to the other dairy sheep breeds in Turkey.

A genetic improvement program for milk yield of Awassi sheep in farm conditions has been carried out since 2005 and supported by the General Directorate of Agricultural Researches and Politics (GDARP). The selection in dairy sheep on the basis of part lactation milk yields is an important issue in terms of decreasing the rearing cost (Ranjan et al., 2005). In addition, as in the 
case of cattle, early identification and culling of low producing sheep could increase the rate of genetic improvement. This can also be achieved by accurate prediction of full lactation milk yield from part yields for sheep since there is a high genetic and phenotypic correlation between part lactation milk yield and complete lactation records (Koul, 1973).

Therefore, the objective of this study is to develop the prediction equations for 150 days milk yields using monthly, cumulative monthly and sequential monthly milk yields for Awassi sheep.

\section{MATERIALS AND METHODS}

The data were taken from the pedigree records and daily milk records of Awassi sheep kept at the GAP International Agricultural Research and Training Center in Diyarbakır, Turkey. For the present study, the monthly milk yield data of about 145 complete lactations were taken for the period from 2004 to 2008. The records with less than 150 days lactation length, ewes with the history of abortion and stillbirth were removed from the study. Data taken for 150 day milk yield, monthly milk yield and cumulative monthly milk yield were used to obtain prediction equations for 150 day milk yield based on part yields and cumulative part yields. Part and complete lactation milk yield of each ewe was calculated by Fleischmann metod (Barillet et al., 1992).

The formulas for predicting 150 day milk yields from part and cumulative monthly yields were as follows,

$$
\begin{gathered}
T M Y 150=a+b_{i}\left(T M Y_{i}\right) \\
T M Y 150=a+\sum_{i=1}^{4} b_{i}\left(T M Y_{i}\right) \\
T M Y 150=a+b_{i}\left(T M Y 0_{i}\right) \\
T M Y 150=a+\sum_{i=1}^{4} b_{i}\left(T M Y 0_{i}\right)
\end{gathered}
$$

where, $T M Y_{150}$ is 150 day milk yield calculated using the Fleischmann metod, $a$ is intercept, $b_{i}$ is regression coefficient, $T M Y_{i}$ is montly milk yield $\left(T M Y_{1}\right.$ : total milk yield produced by a ewe the first month after lambing, $T M Y_{2}$ is total milk yield produced by a ewe the second month after lambing, and so on). $T M Y 0_{\mathrm{i}}$ is total milk yield from lambing to ith month $\left(T M Y 0_{1}\right.$ : total milk yield produced by a ewe the first month after lambing, $T M Y O_{2}$ is total milk yield produced by a ewe the first two months after lambing, and so on)

In equation (1) (E1), single monthly milk yield was used as a regression factor in each analysis. In equation (2) (E2), single monthly milk yields were sequencially added to the model. In equation (3) (E3), cumulative monthly milk yield was used as a regression factor in each analysis. In equation (4) (E4), cumulative monthly milk yields were sequencially added to the model. The data were analyzed using the Proc Reg procedure in SAS (2000).

\section{RESULTS AND DISCUSSION}

\section{Predicting 150 day milk yields from monthly and cumulative monthly milk yields}

The regression factors for estimating 150 day milk yields for monthly yields are presented in Table 1 . Regression coefficients were highly significant $(P<0.01)$ for all single monthly records. The result indicates that 150 day milk yields are depended on monthly milk yields. The highest $R^{2}$ $(0.836)$ value was obtained for $3^{\text {rd }}$ month followed by $2^{\text {th }}(0.756)$ and $4^{\text {th }}(0.659)$ month.

\section{Table 1}

\begin{tabular}{|c|c|c|c|c|}
\hline & Intercept & $b \pm S E_{b}$ & $t$-value & $R^{2}$ \\
\hline$T M Y_{1}$ & 57.18 & $2.983 \pm 0.1853^{* *}$ & 16.10 & 0.600 \\
\hline$T M Y_{2}$ & 43.85 & $3.276 \pm 0.1416^{* *}$ & 23.13 & 0.756 \\
\hline$T M Y_{3}$ & 36.79 & $3.400 \pm 0.1156^{* *}$ & 29.41 & 0.836 \\
\hline$T M Y_{4}$ & 49.16 & $3.569 \pm 0.1970^{* *}$ & 18.11 & 0.659 \\
\hline
\end{tabular}

Regression factors for estimating 150 day milk yield from monthly yields in the Turkish Awassi sheep

The regression factors for estimating 150 day milk yields for cumulative monthly yields are given in Table 2. As in the case of monthly records, all regression coefficients were highly significant $(P<0.01)$ for all cumulative monthly records. This finding suggests that 150 day milk yields are depended on cumulative monthly milk yields, as well. The highest $R^{2}$ value for the first-4 $\left(\mathrm{TMYO}_{4}\right)$ months cumulative yield were 0.982 followed by $0.926,0.797$ and 0.600 for first-3 $\left(\mathrm{TMYO}_{3}\right)$, first-2 $\left(\mathrm{TMYO}_{2}\right)$ and first-1 month $\left(T M Y 0_{1}\right)$ cumulative yield, respectively. 
Table 2

Regression factors for estimating 150 day milk yield from cumulative montly yields in the Turkish Awassi sheep

\begin{tabular}{lcccc}
\hline \hline & Intercept & $b \pm S E_{b}$ & $t$-value & $R^{2}$ \\
\hline$T M Y 0_{1}$ & 57.18 & $2.983 \pm 0.1853^{* *}$ & 16.10 & 0.600 \\
$T M Y 0_{2}$ & 32.91 & $1.846 \pm 0.0708^{* *}$ & 26.06 & 0.797 \\
$T M Y 0_{3}$ & 18.08 & $1.366 \pm 0.0297^{* *}$ & 46.03 & 0.926 \\
$T M Y 0_{4}$ & 7.87 & $1.139 \pm 0.0118+$ & 96.38 & 0.982 \\
\hline \hline
\end{tabular}

$* *(P<0.01)$

$R^{2}$ values obtained were quite high for early monthly and cumulative monthly yields, thus the first-3 months cumulative yields were the best for 150 day milk yield prediction. Awassi sheep in Turkey are milked for five to six months, so prediction on the early part as well as cumulative milk yield could shorten the time for selection for increased complete lactation milk yield. Literature is limited on dairy sheep in terms of this kind of study so the result obtained in this research will be discussed in a technical point of view with dairy cattle studies. Our results are in agreement with the findings from studies on Jersey cattle (Roy and Katpatal, 1989; Khoda and Trivedi (1987), on Sahiwal cows (Shrivastava and Khan, 1989). They reported that the $3^{\text {rd }}, 4^{\text {th }}$ and $5^{\text {th }}$ months of lactation and first-3, first- 4 and first-5 cumulative yields were best for prediction of complete lactation milk yield. On the other hand, Tahir et al. (1983) reported that the $5^{\text {th }}$ month yield and the cumulative yield from the $4^{\text {th }}$ to the $10^{\text {th }}$ month were the best for estimating the lactation milk yield in Niliravi buffaloes.

\section{Predicting 150 day milk yields using sequential combination of monthly milk yields}

The regression factors and $R^{2}$ obtained from the multiple regression analysis of montly milk yield and cumulative monthly milk yields to estimate 150 day milk yield are given in Table 3 and Table 4, respectively. It was observed that $R^{2}$ was increased as the subsequent months were included in the equation. The highest $R^{2}(0.984)$ value was obtained from the equation including the first four months and/or cumulative monthly milk yields followed by the first three, the first two and the first month as $0.945,0.811$ and 0.600 , respectively. It was observed that the first three monthly milk yields could conveniently be used to predict the six month total milk yield. Thus, this could save recording cost and time to identify the best ewes with the highest lactation milk yield. Similar results were reported in cattle, for Jersey (Roy and Katpatal, 1989), for Ongole (Roy, 1980) and for Sahiwal X HF crosses (Gore, 1981).

Table 3

Regression factors and standard errors for estimating 150 days milk yield from sequential combination of monthly milk yields

\begin{tabular}{|c|c|c|c|c|c|}
\hline Intercept & $T M Y 0_{1}$ & $T M Y 0_{2}$ & $\mathrm{TMYO}_{3}$ & $\mathrm{TMYO}_{4}$ & $R^{2}$ \\
\hline 57.18 & $2.983 \pm 0.1853^{* *}$ & & & & 0.600 \\
\hline 32.62 & $-1.151 \pm 0.3247^{*}$ & $2.414 \pm 0.1743^{* *}$ & & & 0.811 \\
\hline 16.92 & $0.304 \pm 0.1909$ & $-1.327 \pm 0.2084^{* *}$ & $2.150 \pm 0.1064^{* *}$ & & 0.945 \\
\hline 7.40 & $0.093 \pm 0.1026$ & $-0.231 \pm 0.1236$ & $-0.133 \pm 0.1251$ & $1.340 \pm 0.0654^{* *}$ & 0.984 \\
\hline
\end{tabular}

${ }^{* *}(P<0.01),{ }^{*}(P<0.05)$

Table 4

Regression factors and standard errors

for estimating 150 day milk yield from sequential combination of cumulative milk yields

\begin{tabular}{|c|c|c|c|c|c|}
\hline Intercept & $T M Y 0_{1}$ & $\mathrm{TMYO}_{2}$ & $\mathrm{TMYO}_{3}$ & $\mathrm{TMYO}_{4}$ & $R^{2}$ \\
\hline 57.18 & $2.983 \pm 0.1853^{* *}$ & & & & 0.600 \\
\hline 32.62 & $-1.151 \pm 0.3247^{*}$ & $2.414 \pm 0.1743^{* *}$ & & & 0.811 \\
\hline 16.92 & $0.304 \pm 0.1909$ & $-1.327 \pm 0.2084^{* *}$ & $2.150 \pm 0.1064^{* *}$ & & 0.945 \\
\hline 7.40 & $0.093 \pm 0.1026$ & $-0.231 \pm 0.1236$ & $-0.133 \pm 0.1251$ & $1.340 \pm 0.0654^{* *}$ & 0.984 \\
\hline
\end{tabular}




\section{Correlations among monthly, cumulative monthly and total lactation milk yields}

The correlations (r-value) among the regression factors and lactation milk yields are presented in Table 5. All coefficeients are significantly different from zero $(P<0.01)$. Regarding single monthly milk yields, the highest r-value (0.914) was observed between the $3^{\text {rd }}$ month milk yield and 150 day milk yield $\left(T M Y_{3}\right.$ and $\left.T M Y_{150}\right)$ followed by the $2^{\text {nd }}(0.869)$, the $4^{\text {th }}(0.812)$ and the $1^{\text {st }}$ (0.775) month milk yield. In terms of cumulative monthly milk yields, the highest r-value (0.991) was observed between the first four months cumulative monhly milk yield and 150 day milk yield $\left(T M Y 0_{4}\right.$ and $\left.T M Y_{150}\right)$ followed by the first-3 (0.962), the first-2 (0.893) and the first-1 (0.775) cumulative lactation milk yields.

\section{Table 5}

\section{Correlation coefficients among cumulative part and total lactation milk yield in Turkish Awassi sheep}

\begin{tabular}{lccccc}
\hline \hline & $T M Y_{30}$ & $T M Y_{60}$ & $T M Y_{90}$ & $T M Y_{120}$ & $T M Y_{150}$ \\
\hline$T M Y_{1}$ & 1.000 & 0.919 & 0.849 & 0.800 & 0.775 \\
$T M Y_{2}$ & 0.697 & 0.923 & 0.929 & 0.894 & 0.869 \\
$T M Y_{3}$ & 0.570 & 0.731 & 0.884 & 0.913 & 0.914 \\
$T M Y_{4}$ & 0.431 & 0.531 & 0.653 & 0.790 & 0.812 \\
$T M Y_{150}$ & 0.775 & 0.893 & 0.962 & 0.991 & \\
\hline \hline
\end{tabular}

\section{CONCLUSION}

Based on the results obtained in this research, it can be concluded that the first three single monthly or the first three cumulative monthly milk yields can be used in multiple regression equations with a quite high accuracy to predict total lactation milk yields in Awassi sheep in Turkey.

\section{REFERENCES}

[1] Barillet, F., Astruc, J. M., De Brauwer, P., Casu, P. S., Fabbri, G., Feddersen, E., Frangos K., Gabina, D., Gama, L. T., Ruiz, T. J. L., Sanna, S. R. (1992): International Regulations for Milk Recording in Sheep. Ins. de Elevage, Int. Committee for Animal Recording Guidelines, Paris, France, pp. $15+$ appendix.

[2] Gore, A. K. K. (1981): Biometrical genetic study on Sahiwal and Sahiwal $\mathrm{x}$ HF crosses. Ph.D. Thesis. J.N.K.V.V. Jabalpur, India.

[3] Khoda, V. K., Trivedi K. R. (1987): Prediction of total lactation yield from part lactation yield in Jersey cows. Indian J. Anim. Sci., 57, 448-52.

[4] Koncagül, S., Akça, N., Vural, M. E., Karataş, A., Bingöl, M. (2012): Zom Koyunlarının Morfolojik Özellikleri. Kafkas Üniv Vet Fak Derg, 18 (5): 829-837.

[5] Koncagül, S., Vural, M. E., Karataş, A., Akça, N., Bingöl M. (2012): Reproductive Performance and Growth Characteristics of Zom Sheep. Kafkas Üniv Vet Fak Derg, (Inpress).

[6] Koul, G. L. (1973): Comparative efficiency of selection indices using part and whole lactation records in Hariana Cattle. Ph. D. Thesis, Agra University, Agra, India.

[7] Ranjan, S. K., Lakhera, M. L., Singh, M. (2005): Development of Prediction Equations for 300 Days Milk Yield from Part Yields, Cumulative part and Sequential monthly Records in Sahiwal Cows. Int. J. of Agri Bio., 7 (4), 574-578.

[8] Roy, M. V. (1981): Studies on genetic trends and relative efficiency of selection on part lactation records in Ongole cattle. Ph. D. Thesis, Rohilkhand University, Bariely, India.

[9] Roy, T. C., Katpatal, B. (1989): Prediction of 300 days milk yields from part lactation records in Jersey cattle. Indian Vet. J., 66, 749-55.

[10] SAS, SAS/STAT. SAS Inst Inc, Cary, NC, USA (2000).

[11] Shrivastava, G. K., Khan, F. H. (1989): Simple regression factor for extending partial yields in Sahiwal cows. Indian Vet. J., 66, 371-373.

[12] Snedecor, G. W., Cochran, W. G. (1967): Statistical Methods, 6th ed. Oxford \& IBH Publishing Co., New Delhi.

[13] Tahir, M., Chaudhary, R. A., Ahmed, N., Hussain, T. (1983): Role of part lactations in sire proving programmes and speeding up selection of Niliravi buffaloes. Indian J. Anim. Sci., 36, 391-393. 